\title{
GEOMORPHOLOGICAL ANALYSIS OF KARST LANDFORMS AT THE MASSO DELLA VECCHIA GEOSITE (SALENTO PENINSULA, ITALY)
}

\author{
GEOMORFLOŠKA ANALIZA KRAŠKIH OBLIK NA OBMOČJU \\ MASSO DELLA VECCHIA \\ (POLOTOK SALENTO, ITALIJA)
}

Paolo SANSÒ ${ }^{1}$

\begin{abstract}
UDC 551.435.8(450.75)

Paolo Sansò: Geomorphological analysis of karst landforms at the Masso della Vecchia geosite (Salento peninsula, Italy)

The presence of a pedestal rock, locally named Masso della Vecchia, marks a site of relevant geological interest (geosite) in the surrounding of Giuggianello village (Salento Peninsula, Apulia region, Italy). This unusual natural landform and similar others occurring in the same area gave birth to myths and legends. A detailed geomorphological analysis of Masso della Vecchia area has been carried out. The site is placed at about $100 \mathrm{~m}$ of altitude on a lower Pleistocene abrasion surface which constitutes the top of the Serra di Poggiardo morphostructural ridge. Locally, the Miocene Pietra Leccese Formation crops out. It is constituted by poorly consolidated, bioturbated, yellowish biomicrites at lower levels rapidly grading upward in massive grainstones rich in glauconite minerals. The entire sequence gently dips northeastward. The geomorphological analysis revealed that the Masso della Vecchia and similar landforms occurring in the area are karstic features produced under a soil cover. Pinnacles, channels, notches, subsoil scallops, half-bells and other typical features have been recognized. The peculiar assemblage of subsoil karst features can be explained taking into account the geological structure, subsoil karst processes and the geomorphological evolution of this area during the Late Pleistocene.

Key words: subsoil karren, geoheritage, Salento, Italy.
\end{abstract}

Izvleček UDK 551.435.8(450.75)

Paolo Sansò: Geomorfološka analiza kraških oblik geoznamenitosti Masso della Vecchia (polotok Salento, Italija)

Prisotnost matične kamnine, ki jo krajevno imenujejo Masso della Vecchia, je pomembna geološka zanimivost $\mathrm{v}$ okolici vasi Giuggianello (polotok Salento, Apulija, Italija). Zaradi nenavadne naravne reliefne oblike te kamnine in mnogih drugih podobnih kamnin, ki se pojavljajo na tem območju, so nastali številni miti in legende. Naredili smo podrobno geomorfološko analizo Masso della Vecchia. Študijsko območje je okoli 100 m nad morjem na abrazijskem območju iz spodnjega pleistocena, ki je pravzaprav vrh morfostrukturnega grebena Serra di Poggiardo. Krajevno se iz kamnin miocenske starosti na površju pojavlja Pietra Leccese. Sestavljen je iz slabo strjenih, bioturbacijskih rumenkastih biomikritov, ki se na nižjih ravneh hitro vzpenjajo $\mathrm{v}$ masivni grainstone, bogat $\mathrm{z}$ mineralom glavkonita. Celotna sekvenca je rahlo nagnjena proti severovzhodu. Geomorfološka analiza je pokazala, da so Masso della Vecchia in podobne reliefne oblike, ki se pojavljajo na območju, kraške in da so nastale pod pokrovom prsti. Prepoznali smo vrhove, kanale, zareze, podtalne fasete, polzvonove in druge tipične oblike. Svojevrsten skupek podtalnih kraških oblik je mogoče razložiti $z$ upoštevanjem geološke strukture, podtalnih kraških procesov in geomorfološkega razvoja tega območja v času poznega pleistocena.

Ključne besede: podtalne škraplje, naravna dediščina, Salento, Italija.

\section{INTRODUCTION}

A natural monument marks a site placed in the surrounding of Giuggianello, a small village of southern Salento (Apulia region) (Fig.1). It is constituted by a pedestal rock called by local people "lu furticiddhu de la vecchia de lu Manni" (i.e. the spindle used by a witch to make yarn) or more simply "Masso della Vecchia" (i.e. the large

${ }^{1}$ Di.S.Te.B.A., Università del Salento, Italy, e-mail: paolo.sanso@unisalento.it

Received/Prejeto: 04.05.2016 


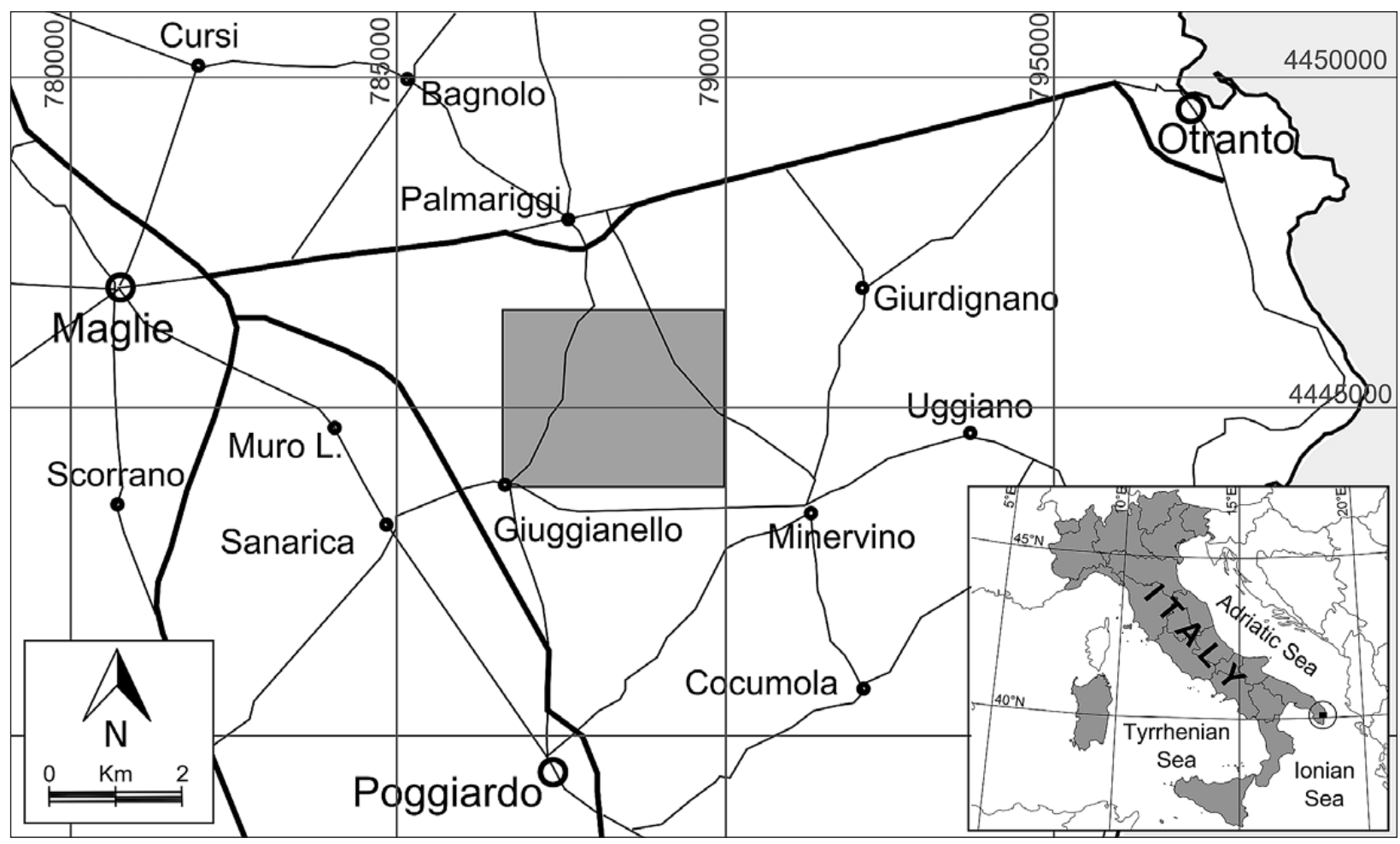

Fig. 1: The grey box indicates the geographical position of Masso della Vecchia area (Giuggianello, Salento Peninsula).

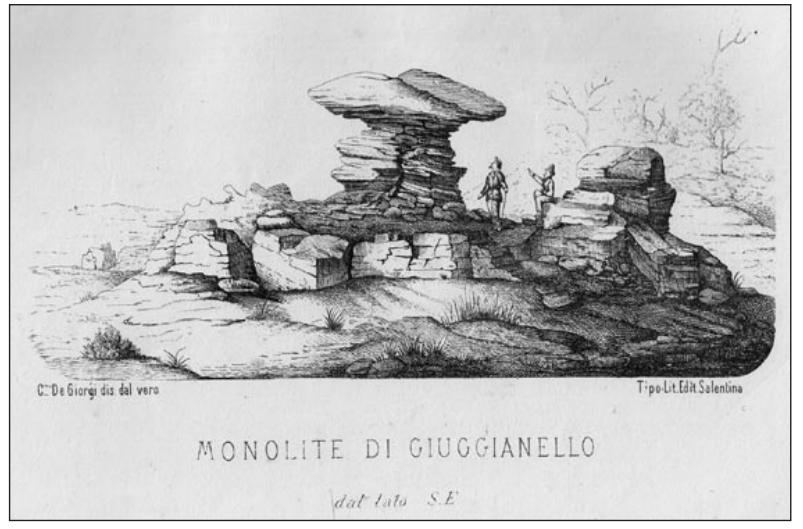

Fig. 2: The Masso della Vecchia pedestal rock in a XIX century drawing of Cosimo De Giorgi.

block of the witch). Numerous local legends arouse from the occurrence of this unusual landform.

De Simone (1867) reported for the first time the presence in the Salento peninsula of this mushroom-like rock, even if he wasn't able to indicate precisely its position. Maggiulli (1871) considered it a megalithic monument whereas Botti (1871) referred its origin to weathering processes reporting examples of similar landforms in Italy ("pile di formaggio" at Elba island, "pietra ballerina" near Nuoro, Sardinia) and in Europe (Central Massif of France, "cheesewring" in Cornwall, "Herkulessaulen" at Bielagrund, Switzerland).
According to De Simone (1872) this singular rock would be that one quoted by Aristotelis' "De Mirabilibus Auscultationibus" reporting the legend that this heavy block was thrown away by Hercules in his fierce battle against Giants. This author accurately describes the size of Masso della Vecchia mushroom-like rock shaped on the Tertiary Pietra Leccese Formation. The pedestal is $2.75 \mathrm{~m}$ high and supports a block showing a perimeter $15.60 \mathrm{~m}$ long, long axis $5.70 \mathrm{~m}$ and short axis $2.85 \mathrm{~m}$; the block thickness at its centre is about $2.30 \mathrm{~m}$ (Fig. 2).

Other unusual rocks can be found in the area. De Simone (1872) noted that in the same place another mushroom-like rock, more than twice larger than the Masso della Vecchia, was broken in piece by a mine few years before. Finally, the author informs readers that the Royal Government classified the Masso della Vecchia as National Monument of First Category. De Giorgi (1879) resumes De Simone (1872) data, reporting also the nearby occurrence of a mushroom-like rock which lost its top stone and of another rock shaped as an anvil. This author refers the development of these particular rocks to weathering process even if he doesn't rule out that these natural landforms could be used as sacred places by prehistoric men.

The geomorphological singularity of the Masso della Vecchia pedestal rock justifies its presence in the inventory of geosites recently realized by the Regione Puglia Administration (Mastronuzzi et al. 2015). 
Notwithstanding all this, no specific research to describe the geomorphological features at Masso della Vecchia site and to explain their genesis and evolution has been carried out so far. Aiming to fill this gap, a geomorphological survey of the area marked by this natu- ral monument has been performed; it defined the main morphogenetic processes responsible for landforms genesis as well as allows the morphogenetic evolution of local landscape to be reconstructed.

\section{GEOLOGICAL AND GEOMORPHOLOGICAL SETTING}

The Salento peninsula is the southernmost emerged part of Adria Plate which constitutes the foreland of both Apenninic and Dinaric orogens. It comprises a Variscan basement covered by a 3-5 km thick Mesozoic carbonate sequence (the Calcari delle Murge unit) overlain by thin Tertiary and Quaternary deposits. The most ancient rocks of this cover were produced by transgressions after the definitive emersion of the Apulian carbonate platform occurred between the end of the Cretaceous and the beginning of Paleogene periods; in some cases, bauxitic deposits can be found between Mesozoic limestones and Paleogene units (Doglioni et al. 1994).

Four sedimentary cycles have been recognized from Neogene to Lower Pleistocene periods (Giudici et al. 2012). The first cycle comprises the Pietra Leccese Formation and the overlying Calcarenite di Andrano Formation. The Miocene sedimentary cycle was interrupted because of the emersion of Salento which prevented the formation of Messinian evaporites. The total thickness of Miocene formations is greater than $150 \mathrm{~m}$ on the eastern side of the peninsula. The second cycle is represented by breccias and conglomerates of the Leuca Formation that was deposited during the Lower Pliocene, reaching a maximum thickness of $30 \mathrm{~m}$. The third sedimentary cycle is represented by the Upper Pliocene Uggiano la Chiesa Formation, composed of wellstratified and fossiliferous biodetritical limestones and yellowish calcareous sands with a maximum thickness of about $80 \mathrm{~m}$. The fourth sedimentary cycle promoted the deposition in the Lower Pleistocene of the Calcareniti del Salento Formation, a very fossiliferous biodetritical calcareous sediment marked by the occurrence of Artica islandica Linneo. Its maximum thickness is of about $60 \mathrm{~m}$. Finally, a number of Middle-Upper Pleistocene deposits related to eustatic sea level change can be found on the Salento peninsula (Hearty \& Dai Pra 1992; Mastronuzzi et al. 2007).

Three main tectonic events affected the Salento Peninsula during the Eo-Oligocene, the Middle Pliocene, and the Middle Pleistocene periods. In particular, the most recent tectonic phase was responsible for the final uplift of the Apulia foreland after the general subsidence took place in the early Miocene period; uplift ended at Marine Isotope Stages (MIS) 9.3, about 330 ka BP (Mastronuzzi et al. 2007). Since then, maximum uplift rates have been recorded only in the Taranto area $(0.25 \mathrm{~m} / \mathrm{ka}$ according to Ferranti et al. 2006), whereas they decrease to zero in the southernmost part of the region. Finally, a slow subsidence has been recorded along the Salento peninsula coast during the last four millennia (Mastronuzzi \& Sansò 2014).

The Salento peninsula is a low-elevated landscape composed of a number of Pleistocene plains placed at different altitude between sea level and $160 \mathrm{~m}$ of elevation. They are bordered by geomorphically degraded fault scarps, mostly elongated in NW-SE and NNW-SSE directions, by differential erosion scarps, and by relict cliffs. Along the Salento peninsula coast a number of marine terraces, produced by the superimposition of regional uplift and glacio-eustatic sea level changes occurred since the Middle Pleistocene period, can be recognized.

In particular, the inner and western parts of the Salento Peninsula show a landscape produced by contact karst processes made of wide karstic surfaces, remnants of a Middle Pleistocene sedimentary cover and morphostructural ridges. The karstic surfaces belong to a re-exhumed landscape shaped between the Lower and the Middle Pleistocene whereas the morphostructural ridges are made of Mesozoic dolomitic-carbonatic units and show a polycyclic landscape (Selleri et al. 2003). However, sinkholes are the main karstic landforms in many sectors of Salento affecting all outcropping carbonate rocks, including the Cretaceous limestone, the Oligocene, Miocene, and Plio-Pleistocene calcarenites, and the middle-upper Pleistocene terraced marine deposits. They are widespread especially along the low elevated rocky platforms occurring both on the Adriatic and Ionian coasts and display different typologies and states of activity (Delle Rose \& Parise 2002; Bruno et al. 2008). 


\section{GEOMORPHOLOGICAL AND GEOLOGICAL FEATURES OF MASSO DELLA VECCHIA GEOSITE}

The Masso della Vecchia pedestal rock is placed on the top surface of a morphostructural ridge, locally named Serra di Poggiardo, bordered by two low NNW-SSE trending scarps. Its top surface is a plain mainly shaped on Cretaceous limestone but also on Oligocene, $\mathrm{Mi}$ ocene and Lower Pliocene units (Fig. 3). It is placed at about $100 \mathrm{~m}$ above m.s.l. and gently slopes from the SSE to the NNW. A number of wide and shallow karstic depressions can be recognized on this plain surface. From a genetic point of view, it could be referred to a marine abrasion surface shaped at the end of Lower Pleistocene while along the eastern Salento coastal slope the Porto Miggiano calcarenites were depositing (Tropeano et al. 2004).

Locally, on the ridge top surface three main lithostratigraphic units crop out (the Calcari di Altamura Formation, the Pietra Leccese Formation, the Calcareniti di Andrano Formation), arranged in a monoclinal gently dipping towards NNW (Fig. 4). Two younger units (the Leuca Formation and the Sabbie di Uggiano Formation) can be recognized in correspondence of the lower elevated plains stretching at the foot of Serra di Poggiardo on its western and eastern slopes (Bossio et al. 2005).

The Calcari di Altamura Formation is a thick, shallow water carbonate succession deposited in shelf interior environments. In the studied area this unit is represented by a peritidal succession showing thin and rare inter-supratidal algal mats (stromatolites) and marked by quite common discontinuous concentrations of rudist fragments and bioclastic grainstone as well as frequent flat pebble intraformational breccias. The Calcari di Altamura Formation has been referred to the late Campanian - early Maastrichtian (Parente 1994). The remnants of a bauxitic cover can be recognized on the Cretaceous limestones; it is in some places buried under small patches of two Oligocene lithostratigraphic units - the Galatone Formation and the Lecce Formation -, none cropping out in the studied area. The Salento bauxite derived by the erosion of a weathered pristine deposit formed most likely during the middle Campanian emersion event under dry warm climatic conditions (Mongelli et al. 2015).

The Pietra Leccese Formation is typically represented by biomicrites, badly stratified in thick beds, with prevalent calcareous plankton, generally straw-coloured, green in colour only in the upper part due to the abundance of glauconite. The formation is transgressive on different pre-Neogene units through a conglomeratic level marked by phosphatic nodules or pebbles and macrofossils. Occasionally, this level is replaced by a phosphatic film covering surfaces or filling bedrock cavities (Mazzei et al. 2009).

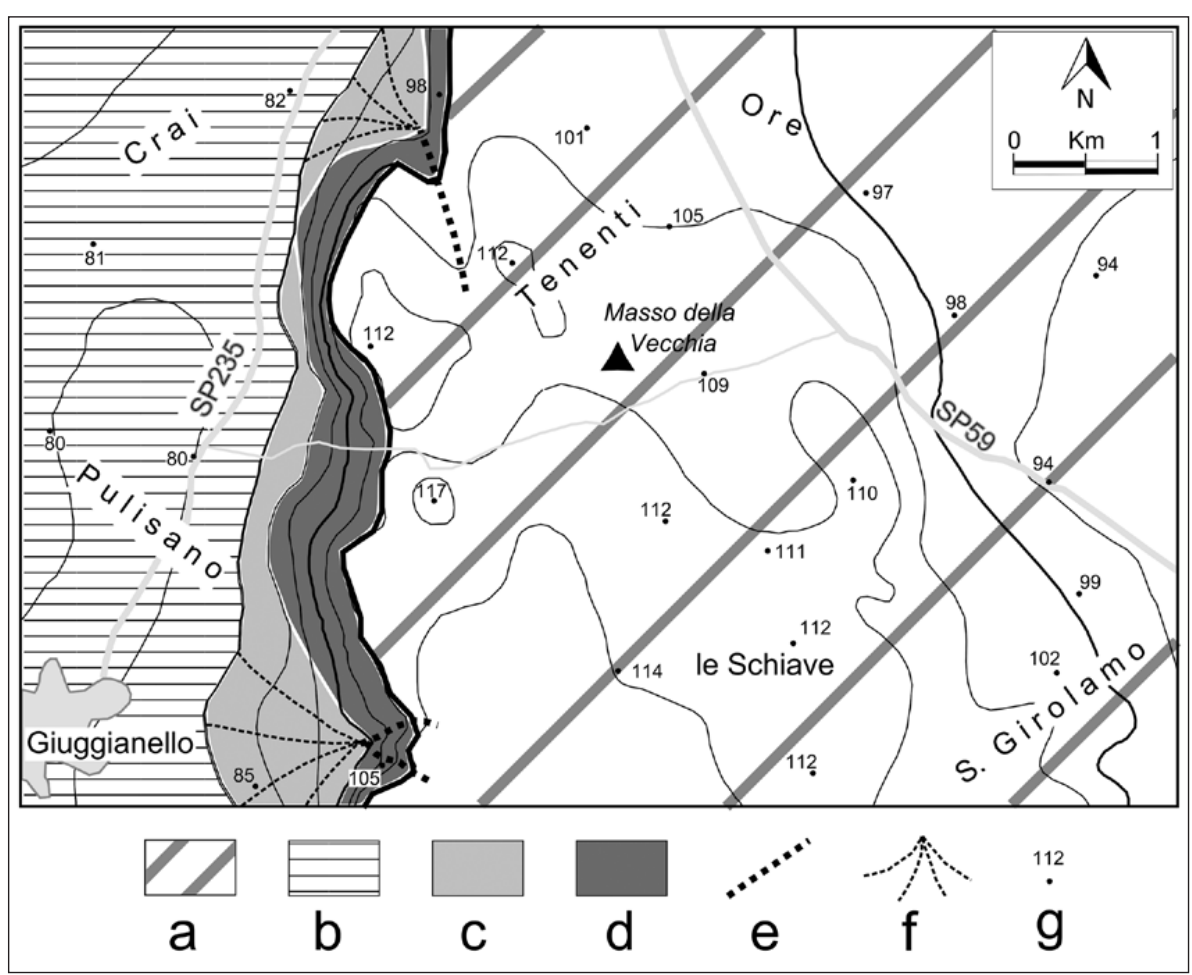

Fig. 3: Geomorphological map of the Masso della Vecchia area.

Legend: a - Serra di Poggiardo top abrasion plain (Lower Pleistocene); $b$ - denudation surface shaped on Pliocene units; $c$-slope scree; $d$ - fault scarp; $e$ - incised channels; $f$-talus cone; $g$ - elevation point. Black triangle marks the Masso della Vecchia position. 


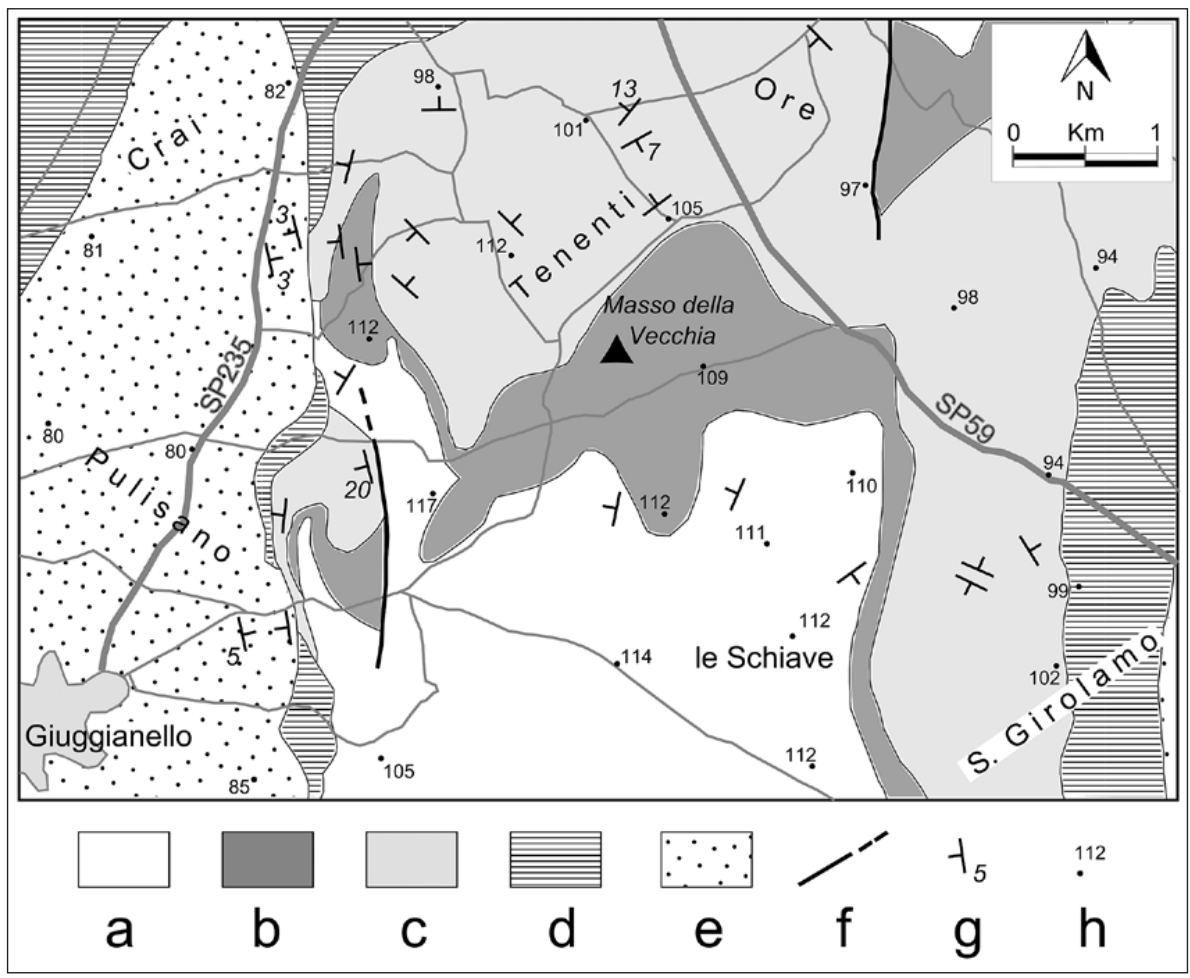

Fig. 4: Geological map of Masso della Vecchia area.

Legend: a - Cretaceous limestone; $b$ - Pietra Leccese Formation (Upper Miocene); c - Calcarenite di Andrano Formation (Upper Miocene); $d$ - Leuca Formation (Lower Pliocene); e - Sabbie di Uggiano Formation (Upper Pliocene); $f$-fault; $g$ - strata attitude; $h$ - elevation point.

In the studied area three distinct lithofacies have been surveyed. The base is marked by a brownish conglomeratic level, about $20-30 \mathrm{~cm}$ thick, made of partly phosphatized limestone pebbles, phosphate nodules, numerous phosphastized fossils and reworked bauxitic pisoliths. Yellowish biomicrites made of prevailing calcareous plancton with variable cementation follows upward; this level is constitutes by layers up to $2 \mathrm{~m}$ thick showing sparse fossils (mainly pectinids) and several bioturbated levels. The local sequence is closed by greenish glauconitic biomicrites, without stratification, very rich in fossils in the uppermost levels, often clustered in layers, and in small brownish phosphatized grains.

The Pietra Leccese Formation has been referred to the late Burdigalian-early Messinian (Mazzei et al. 2009). Its maximum thickness is about $90 \mathrm{~m}$ in the Lecce type area whereas it is about $35 \mathrm{~m}$ in the Cursi-Melpignano area and only $17 \mathrm{~m}$ in the studied area (Bossio et al.
2005). The relatively small thickness of this unit in comparison with its duration (approximately $11 \mathrm{Ma}$ ) is interpreted as a consequence of repeated action of marine currents that inhibited deposition and/or eroded the previously deposited sediments. The related hiatuses are generally outlined by the presence of more or less abundant glauconite grains, a typical mineral of dynamic marine environment.

The Pietra leccese Formation is everywhere overlied by the Calcareniti di Andrano Formation which represents the regressive sequence of the Late Miocene sedimentary cycle. This cycle was interrupted by the uplift of Salento peninsula occurred just before Messinian salinity crisis. The Calcareniti di Andrano Formation reaches a thickness of about 50 metres; it is made of different carbonatic deposits which are well stratified and very fossiliferous. The unit can be entirely referred to the preevaporitic Messinian.

\section{GEOMORPHOLOGICAL FEATURES OF THE MASSO DELLA VECCHIA GEOSITE}

A detailed geomorphological survey has been carried out aiming to provide a quantitative description of the singular landforms occurring at Masso della Vecchia geosite as well as to define their genesis and evolution.
The survey allows four groups of landforms marked by peculiar features to be identified which are spatially arranged in belts stretching roughly in SW-NE direction as well as two sinkholes (Fig. 5). 

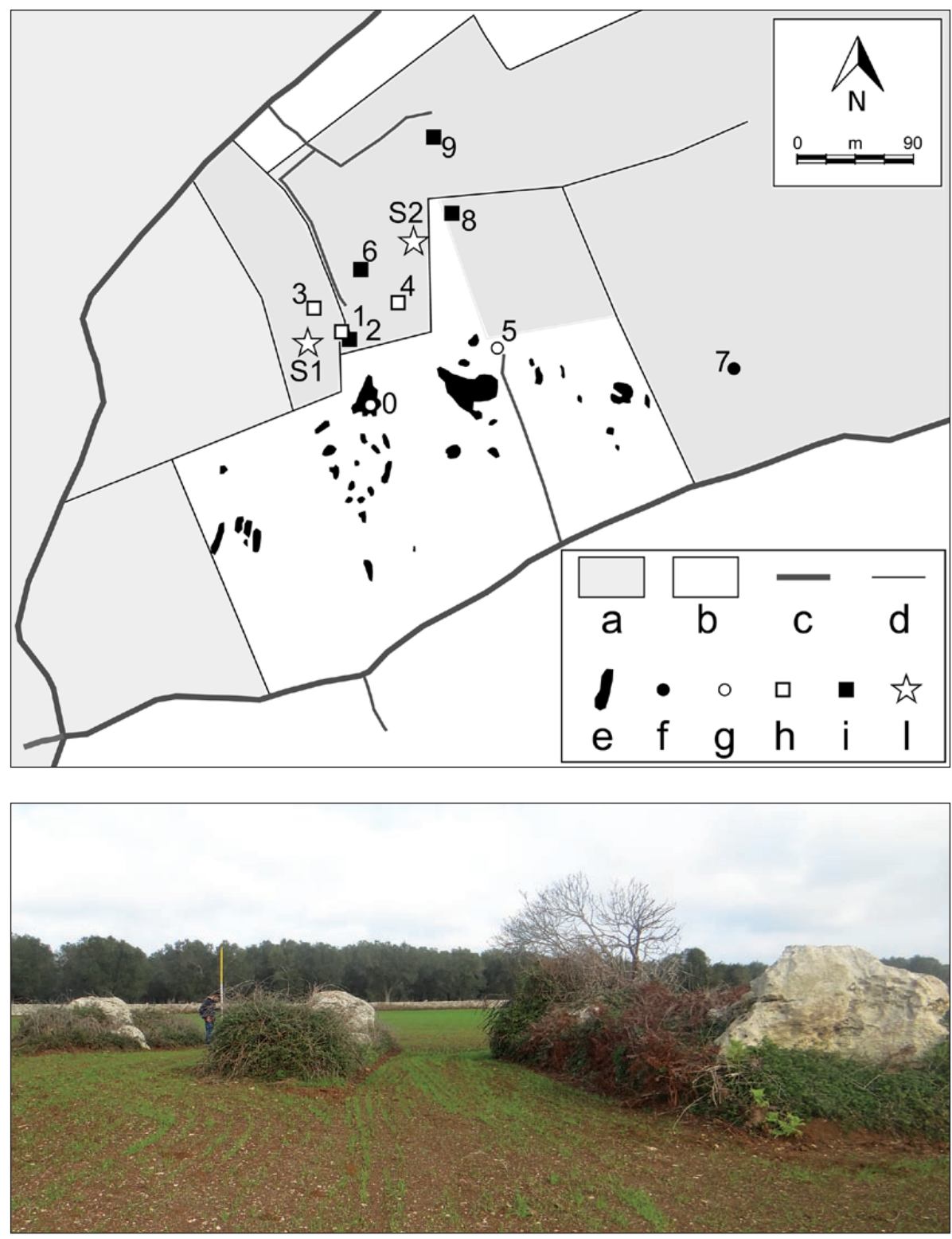

Fig. 5: Spatial distribution of blocks surveyed in the Masso della Vecchia area.

Legend: $a$ - olive grove; $b$ - cultivated field; $c$ - rural road; $d$ - dry-stone wall; e - subsoil pinnacle; $f$ - Group 1 blocks; g-Group 2 blocks; $h$ - Group 3 blocks; $i$ - Group 4 blocks; $l$ karstic sinkhole.

Fig. 6: A view of rock pinnacles which studded a cultivated field belonging to the Group 1. Pinnacles shown in the photo are one parallel each other and elongated in NE-SW direction; they are divided by narrow corridors, about 4-5 m large.

\section{a) Groups of peculiar landforms}

Starting from the SE, the first group is formed by elongated rock pinnacles which studded a cultivated field; pinnacles in some cases are one parallel each other and divided by narrow corridors, about 4-5 m large (Fig. 6). Most of pinnacles were modified by farmers that ripped and accumulated rock slabs around main outcroppings. Pinnacles are about $2 \mathrm{~m}$ high and $10 \mathrm{~m}$ long and are shaped into the Pietra Leccese yellowish biomicrites. The pinnacle surface shows subsoil karstic microforms like cavernous weathering and subsoil scallops.

The small group of pinnacles placed to the easternmost part of the studied area (blocks 7) can be referred to this group. They are up to $1.6 \mathrm{~m}$ high, about $4.5 \mathrm{~m}$ long and $2.0 \mathrm{~m}$ large. They show two different rock sur- faces: the lower surface, extended nearly vertically from soil level up to $1.0 \mathrm{~m}$, is marked by well-developed subsoil scallops whereas a smooth gentler surface occurred in the upper part. A break-in slope separates the two surfaces (Fig. 7).

Rocky outcrops prevail northwestward where the second group of blocks can be found just at the border between olive groves and cultivate fields. This group is marked by pedestal rocks included the suggestive Masso della Vecchia (block 0), the mushroom-like rock described in the previous chapter (Fig. 8). Its stalk is made by three strata of yellowish biomicrites showing in some areas cavernous weathering whereas the capstone is made of a massive glauconitic layer. The pedestal rock stands on a rocky platform, affected during the XIX century by 


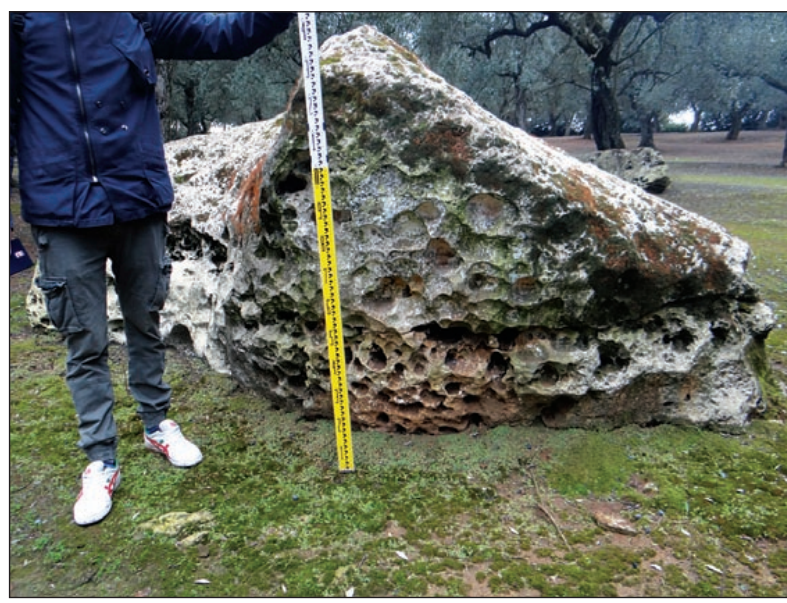

Fig. 7: The surface of block 7, belonging to group 1, is affected by well-developed subsoil scallops (sensu Zseni 2009) and cavernous weathering.

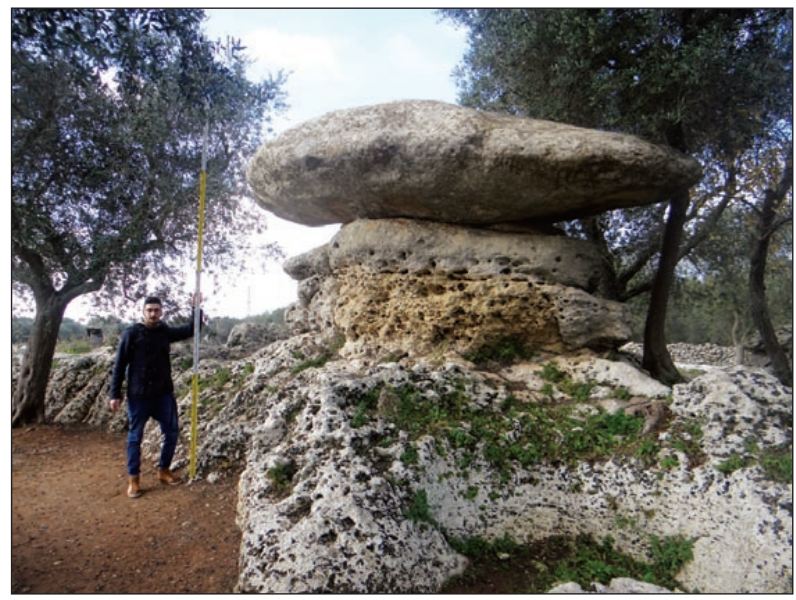

Fig. 8: The Masso della Vecchia pedestal rock (block 0, group 2) viewed from NW. The top block is made of a massive glauconitic layer and has a perimeter $15.60 \mathrm{~m}$ long, long axis $5.70 \mathrm{~m}$ and short axis $2.85 \mathrm{~m}$; the block thickness at its centre is about $2.30 \mathrm{~m}$. Three strata of yellowish biomicrites showing in some areas cavernous weathering constitute the stalk.

a small quarry activity (De Giorgi 1879), bordered by two main karstic corridors developed along main joints.

The same lithological sequence gives rise to another less prominent pedestal rock (block 5) about 120 metres to the northeast of the Masso della Vecchia. The rock stalk is about $1.0 \mathrm{~m}$ high from soil surface and is constituted by weakly cemented, laminated and bioturbated yellowish biomicrites whereas the top block is about $0.8 \mathrm{~m}$ thick, about $5.4 \mathrm{~m}$ long and $3.0 \mathrm{~m}$ large (Fig. 9).

The third group is placed inside a wide olive grove and comprises rocks showing a prominent notch at the base. Block 1 offers the best example; it has an ellipsoidal shape (long axis length $9.5 \mathrm{~m}$, short axis length $6.0 \mathrm{~m}$ ) and elevates about $2.3 \mathrm{~m}$ from ground surface (Fig. 10).

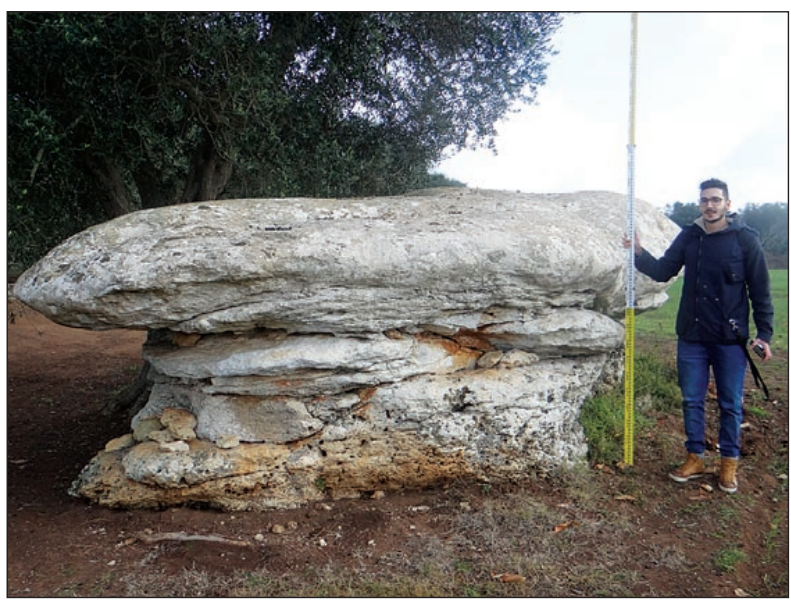

Fig. 9: A view of block 5 (group 2) from south. It is a less prominent pedestal rock showing a stalk about $1.0 \mathrm{~m}$ high. The lithostructural difference between the cap rock, made of massive glauconitic calcarenites, and the stalk, constituted by laminated biomicrites, can be easily recognized.

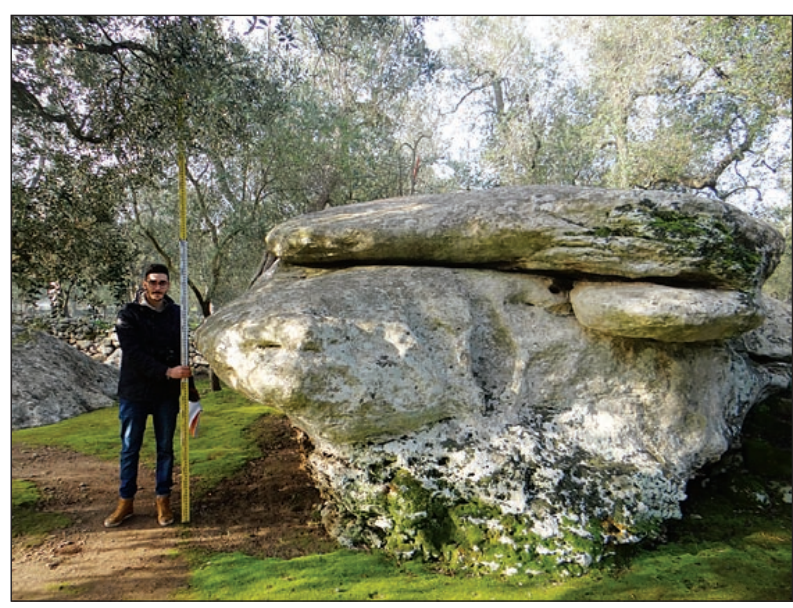

Fig. 10: Block 1 (group 3) shows a well-developed notch at its base. Notch is about $1.6 \mathrm{~m}$ deep and shows its edge is at about $1.3 \mathrm{~m}$ from the soil surface. On the foreground a half-bell can be recognized.

A notch marks the base of the block; notch's edge is at about $1.3 \mathrm{~m}$ from the soil surface whereas the maximum depth of about $1.6 \mathrm{~m}$ is reached at the block base. The lower section of the notch (about $0.8 \mathrm{~m}$ from soil surface) is shaped on the yellow biomicrites, the top on a massive glauconitic layer.

The last group comprises low karren pinnacles divides by narrow depressions filled by soil developed along main joints (grikes), striking about N150E-N170E. Pinnacles are bordered at ground level by subcutaneous channels with subcircular transverse section up to $50 \mathrm{~cm}$ high and $20-30 \mathrm{~cm}$ wide (Fig. 11). In Fig. 12 the peculiar profiles of some blocks surveyed at Masso della Vecchia area are reported. 


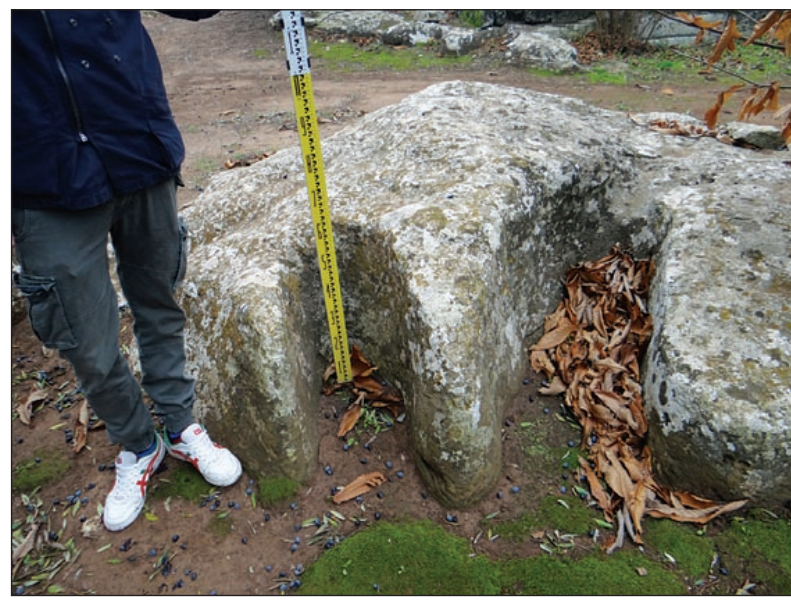

Fig. 11: A view the subcutaneous channels with subcircular transverse section that mark the borders of blocks belonging to the Group 4.

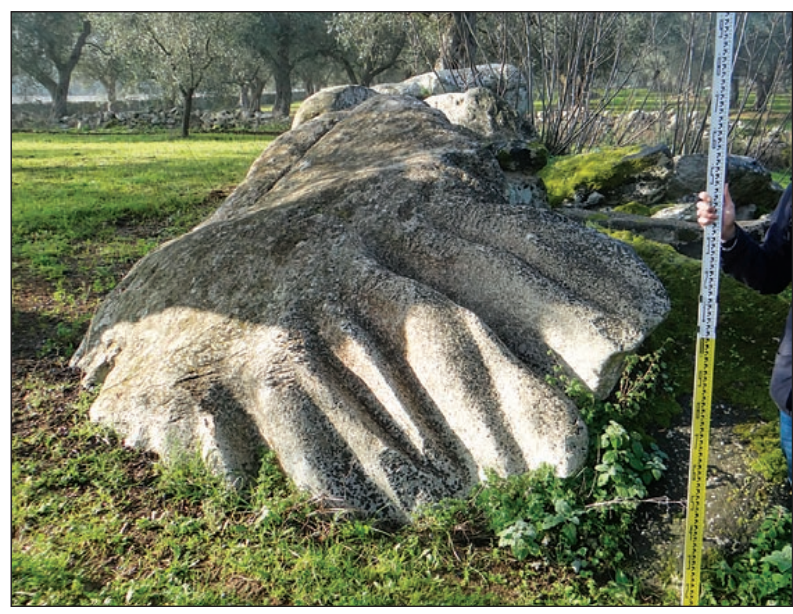

Fig. 14: The sinkhole S1 has been partly filled by farmers with rock slabs. The surface of one of these slab is marked by well-developed subcutaneous channels that, accordingly to the local traditions, resembles the Hercules' foot.

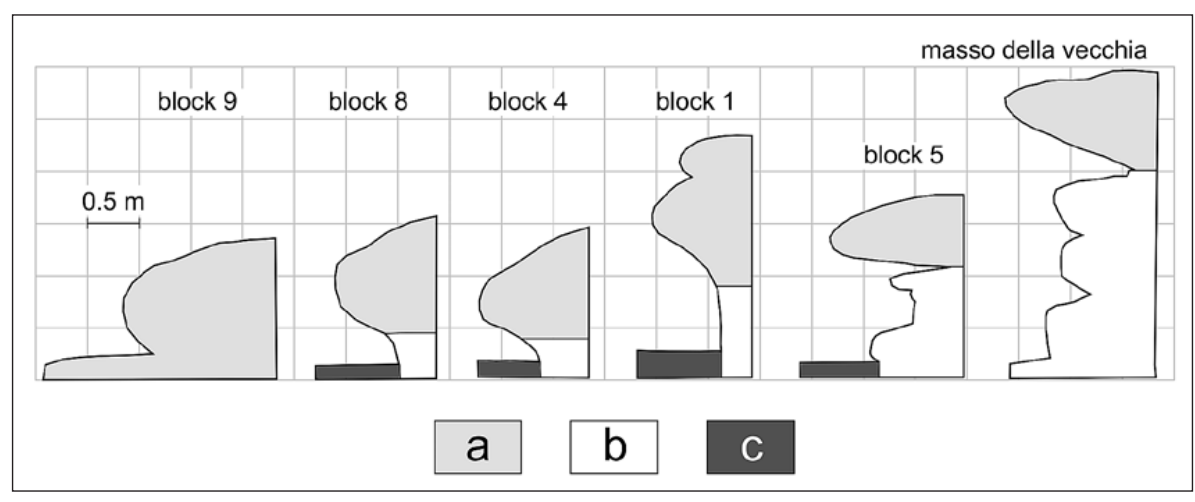

Fig. 12: Peculiar profiles of some blocks surveyed at Masso della Vecchia area. Legend: a - massive grainstone; $b$ - bioturbated or laminated biomicrites; $c$-soil.

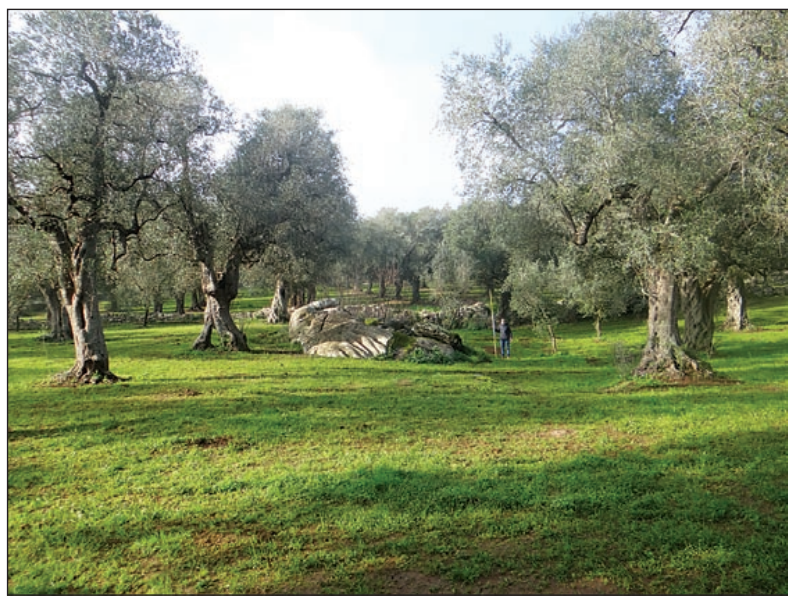

Fig. 13: The sinkhole S1 opens at the bottom of a morphological depression, roughly circular in shape, showing a diameter of $50 \mathrm{~m}$.

\section{b) sinkholes}

Two sinkholes have been surveyed in the third group area (S1 and S2 in Fig. 5). The largest one (S1) has been partly filled by farmers with rock slabs (Fig. 13), one of

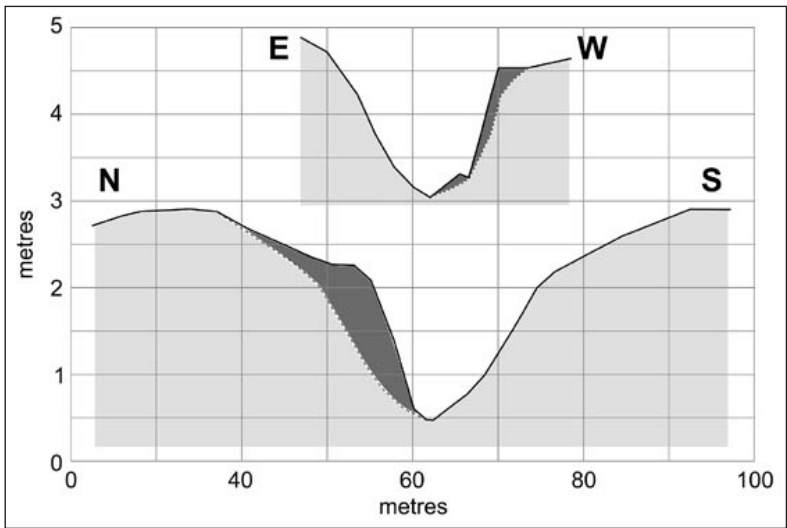

Fig. 15: N-S (below) and E-W (above) cross profiles of sinkhole S1. The sinkhole shows an elliptical shape with main axis about $50 \mathrm{~m}$ long. Sinkhole bottom is about $2 \mathrm{~m}$ lower than surrounding level topographic surface.

them showing well-developed rundkarren (subcutaneous channels sensu Slabe 1999) (Fig. 14). The sinkhole S1 opens at the bottom of a roughly circular morphological 
depression, about $2 \mathrm{~m}$ lower than surrounding surface, showing a diameter of $50 \mathrm{~m}$ (Fig. 15). On the other hand, sinkhole S2 is quite entirely covered by stone blocks and vegetation so that its morphology cannot surveyed.

According to the genetic classification of sinkholes proposed by Gutierrez et al. (2014) it is possible to refer the S1 sinkhole to a cover suffosion sinkhole since it result from both subsurface dissolution and downward gravitational movement of overlying material. S1 sinkhole formed most likely by downward migration of residual soil cover (suffosion process) into major conduits occurring into the bedrock.

\section{DISCUSSION}

The geomorphological analysis of Masso della Vecchia area points out an epikarst marked by peculiar landforms shaped on the Miocene Pietra Leccese Formation such as pinnacles, channels, notches, subsoil scallops, half-bells and so on. The epikarst consists of a near surface zone of weathered rock with high secondary porosity that can outcrop directly at the surface or occur immediately beneath the soil (Williams 2008). The epikarst is tipically $3-10 \mathrm{~m}$ deep but its characteristics can vary considerably according to lithology and geomorphological history. The high porosity and permeability of the epikarst arises from an intense carbonate solution because of proximity to the main source of $\mathrm{CO}_{2}$ production in the soil. Soil, in fact, has an important role in the evolution of different karst features (Zseni 2009). In general, forms which develop in open-air conditions are fretted and sharp, having been subjected to much more selective corrosion due to episodic dissolution by rainwater so that only the rapidly soluble constituents of the rock will be removed. On the contrary, the solution of limestone is more intense under a soil cover due to the higher $\mathrm{CO}_{2}$ concentration and the longer time period of direct water-rock contact. In the case of subsoil solution, in fact, $\mathrm{CO}_{2}$ and other acids produced by the breakdown of the organic matter by microorganisms living in the soil add to the $\mathrm{CO}_{2}$ dissolved by rainwater from the air. The macroflora produces $\mathrm{CO}_{2}$ directly through respiration of roots. For this the network of fissures through which percolation water passes is widened by dissolution near the surface but the extent and frequency of widening diminished gradually with depth. Solutionally enlarged joints taper downwards and become less numerous (Williams 1983). Since soil is often washed down into the larger grikes, lowering of the soil surface down the developing cleft, possibly also with soil loss into near surface cave systems, can result. The distribution of subsoil solutional landforms depends on soil moisture, drainage rates, soil texture, soil depth, water-flow rates, slope, vegetation, and the nature of the limestone.
Numerous classifications of subsoil karst landforms have been proposed so far (e.g. Bögli 1960; Jennings 1971, 1985; Gams 1976; Slabe 1999; Ford \& Williams 2007; Slabe \& Liu 2009); in this paper the classification of Zseni (2009) has been adopted.

The influence of local stratigraphic sequence as well as the geological structure on karstic process can explain the present morphology of the local landscape. Starting from an even abrasion plain presently placed at about $100 \mathrm{~m}$ of elevation, karstic processes have been responsible for the geomorphological evolution of the area (Fig. 16). Due to the geological structure the yellowish laminated biomicrites crop out at Group 1 area; subsoil solution has been responsible for the widening of main fracture planes and for the development of elongated pinnacles, which became more and more prominent as soil level lowered due to corridors deepening and widening. The occurrence of the deep karstified Mesozoic limestone basement close to ground surface enhanced surface lowering in response to soil transfer in epikarst cavities.

In Group 2 area, a massive grainstone bed overlies yellowish laminated biomicrites. Here differential weathering due to soil cover has been responsible for the modelling of some pedestal rocks, whose height lowers from SSW to NNE. Historical data indicate that at least two large pedestal rocks have been destroyed.

In Group 3 area, deep and high solution notches formed along the border of larger outcrops, particularly at the contact between massive grainstone/yellowish laminated biomicrites.

Finally in Group 4 area, solution channels and subsoil enlargement of main joints affecting massive grainstone outcroppings can be detected.

The geomorphological analysis of the local landscape suggests that the subsoil karstic process responsible for the particular morphology of Masso della Vecchia area can be referred to a morphogenetic phase occurred in the Upper Pleistocene. In fact, in this period a SW-NE extensional tectonic phase reactivated the NW-SE and 


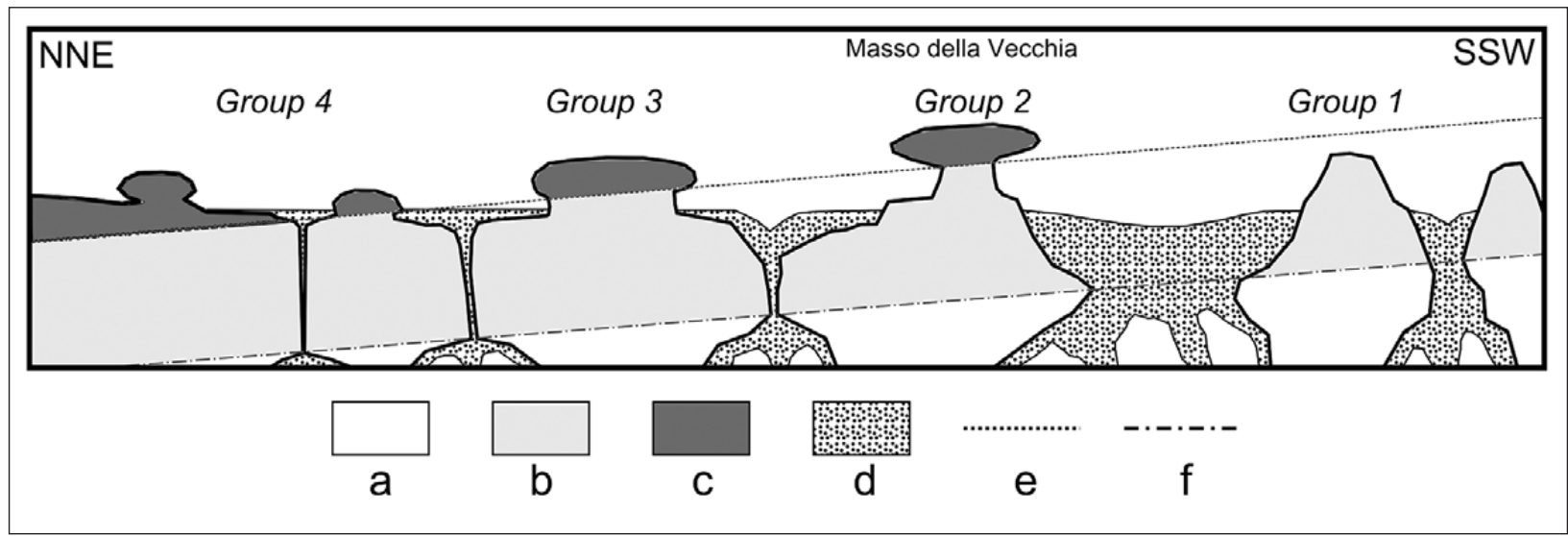

Fig. 16: Geomorphological scheme of subsoil karst landforms surveyed at Masso della Vecchia area.

Legend: $a$-Cretaceous limestone; $b$ - yellow laminated or bioturbated biomicrite (Pietra Leccese Formation, Upper Miocene); $c$ - greenish massive glauconitic bed (Pietra Leccese Formation, Upper Miocene); $d$ - soil cover; e - strata surface; $f$ - transgressive surface.

NNE-SSW faults (Di Bucci et al. 2009, 2011) influencing karst landforms development (Festa et al. 2012; Pepe $\&$ Parise 2014) under humid-warm climatic conditions which promoted intense subsoil karst processes responsible for the widening of joints and cutters development in Pietra Leccese Formation. These processes are well documented in literature since cutters, locally named "ventarole", preserve in their filling a rich vertebrate fossil

phauna that refers subsoil karst development to the Last Interglacial Period (Pandolfi et al., in press). Moreover, the same morphogenetic phase most likely promoted the development of numerous solution pipes in homogenous Pliocene and Pleistocene calcarenites cropping out at several coastal areas of Salento peninsula (Marsico et al. 2003; De Waele et al. 2010).

\section{CONCLUSIONS}

The assemblage of peculiar landforms occurring in the Masso della Vecchia area can be explained taking into account the geological characteristics and the geomorphological evolution of Serra di Poggiardo area. An abrasion surface formed during lower Pleistocene, presently at about $100 \mathrm{~m}$ of altitude, cut strata belonging to the Miocene Pietra Leccese Formation which are locally arranged in a monoclinal structure slightly dipping northeastward.

Starting from this abrasion surface, subsoil karst processes have been responsible for the soil surface lowering due to joints enlargement. The particular lithostratigraphical characteristics of Pietra Leccese Formation and the gently dipping of strata to the NE justify the occurrence of pinnacles where poorly consolidated, bioturbated, yellowish biomicrites crop out. Pedestal rocks, notches and grikes formed where weak biomicrites are covered by massive grainstones. Smaller subsoil karren produced by karst processes are recognizable such as subcutaneous channels, subsoil scallops and half-bells.

The morphogenetic phase responsible for the development of Masso della Vecchia landforms assemblage can be referred to the Last Interglacial Period when a tectonic extensional phase along with warm humid climatic conditions promoted subsoil karstic processes.

The present research could be the first step for the geotouristic promotion of this very peculiar site of Salento peninsula aiming to improve significantly the cultural touristic offer in the Salento peninsula and to increase the number of Italian and foreign tourists during lowseason periods. 


\section{REFERENCES}

Bögli, A., 1960: Kalklösung und Karrenbildung.- Zeitschrift für Geomorphologie, Supplementband 2, 4-21.

Bossio, A., Mazzei, R., Monteforti, B. \& G. Salvatorini, 2005: Stratigrafia del Neogene e Quaternario del Salento sud-orientale (con rilevamento geologico alla scala 1:25.000).- Geologica Romana, 38, 31-60.

Botti, U., 1871: Le Caverne del Capo di Leuca. Tipografia Salentina, Lecce.

Bruno, E., Calcaterra, D. \& M. Parise, 2008: Development and morphometry of sinkholes in coastal plains of Apulia, southern Italy: Preliminary sinkhole susceptibility assessment.- Engineering Geology, 99, 198-209. DOI: https://doi.org/10.1016/j. enggeo.2007.11.017

De Giorgi, C., 1879: I monumenti megalitici di Muro, di Minervino e di Giuggianello in Provincia di Lecce. La Natura, Potenza.

Delle Rose, M. \& M. Parise, 2002: Karst subsidence in south-central Apulia Italy.- International Journal of Speleology 31, 1/4, 181-199. DOI: https://doi. org/10.5038/1827-806x.31.1.11

De Simone, L.G., 1867: Eliafda, ovvero discorso delle origini dei popoli di Terra d'Otranto. Eco dei due mari, 4, 25-29. Tipografia Misurale, Taranto.

De Simone, L. G., 1872: Di un ipogeo messapico scoperto il 30 Agosto 1872 nelle rovine di Rusce e delle origini de' popoli di Terra d'Otranto. Lecce, Tip. Editrice Salentina.

De Waele, J., Lauritzen, S.E. \& M. Parise, 2010: On the formation of dissolution pipes in Quaternary coastal calcareous arenites in Mediterranean settings. Earth Surface Processes and Landforms, 36, 143157. DOI: https://doi.org/10.1002/esp.2022

Di Bucci, D., Coccia, S., Fracassi, U., Iurilli, V., Mastronuzzi, G., Palmentola, G., Sansò, P., Selleri, G. \& G. Valensise, 2009: Late Quaternary deformation of the southern Adriatic foreland (Southern Italy) from mesostructural data: preliminary results.- Boll. Soc. Geol. It., 128, 33-46.

Di Bucci, D., Caputo, R., Mastronuzzi, G., Fracassi, U., Selleri, G. \& P. Sansò, 2011: First evidence of Late Quaternary tectonics from joint analysis in the southern Adriatic foreland (Italy).- Journal of Geodynamics, 51, 141-155.

Doglioni, C., Mongelli, F. \& P. Pieri, 1994: The Puglia uplift (SE Italy): an anomaly in the foreland of the Apenninic subduction due to buckling of a thick continental lithosphere.- Tectonics, 13, 1309-1321. DOI: https://doi.org/10.1029/94tc01501
Ferranti, L., Antonioli, F., Mauz, B., Amorosi, A., Dai Prà, G., Mastronuzzi, G., Monaco, C., Orrù, P., Pappalardo, M., Radtke, U., Renda, P., Romano, P., Sansò, P. \& V. Verrubbi, 2006: Markers of the last interglacial sea level high stand along the coast of Italy: tectonic implications.- Quaternary International, 145-146, 30-54. DOI: https://doi.org/10.1016/j. quaint.2005.07.009

Festa, V., Fiore, A., Parise, M. \& A. Siniscalchi, 2012: Sinkhole evolution in the Apulian karst of southern Italy: a case study, with some considerations on sinkhole hazards.- Journal of Cave and Karst Studies, 74, 2, 137-147. DOI: https://doi. org/10.4311/2011jcks0211

Ford, D.C. \& P.W. Williams, 2007: Karst Hydrogeology and Geomorphology. John Wiley \& Sons, Chichester, 578 pp, England. DOI: https://doi. org/10.1002/9781118684986.ch5

Gams, I., 1976: Forms of subsoil karst.- In: Proceedings of the $6^{\text {th }}$ International Congress of Speleology, Olomouc. Academia, 169-179, Praha.

Giudici, M., Margiotta, S., Mazzone, F., Negri, S. \& C. Vassena, 2012: Modelling hydrostratigraphy and groundwater flow of a fractured and karst aquifer in a Mediterranean basin (Salento peninsula, southeastern Italy).- Environ. Earth Sci., 67, 7, 1891-1907. DOI: https://doi.org/10.1007/s12665-012-1631-1

Gutierrez, F., Parise, M., De Waele, J. \& H. Jourde, 2014: A review on natural and human-induced geohazards and impacts in karst.- Earth Science Reviews, 138, 61-88. DOI: https://doi.org/10.1016/j. earscirev.2014.08.002

Hearty, P.J. \& G. Dai Pra, 1992: The age and stratigraphy of middle Pleistocene and younger deposits along the Gulf of Taranto (southeast Italy).- Journal of Coastal Research, 8, 4, 882-905.

Jennings, J. N., 1971: Karst. Australian National University Press, pp. 252, Canberra.

Jennings, J. N., 1985: Karst Geomorphology. Basil Blackwell, pp. 293, New York.

Maggiulli, L., 1871: Monografia di Muro Leccese. Tip. Editrice Salentina, pp. 81, Lecce.

Marsico, A., Selleri, G., Mastronuzzi, G., Sansò, P. \& N. Walsh, 2003: Cryptokarst: a case-study of the Quaternary landforms of southern Apulia (southern Italy).- Acta Carsologica, 32, 2, 147-159.

Mastronuzzi, G., Quinif, Y., Sansò, P. \& G. Selleri, 2007: Middle-Late Pleistocene polycyclic evolution of a geologically stable coastal area (southern Apulia, Italy).- Geomorphology, 86, 393-408. DOI: https:// doi.org/10.1016/j.geomorph.2006.09.014 
Mastronuzzi, G. \& P. Sansò, 2014: Coastal towers and historical sea level change along the Salento coast (southern Apulia, Italy).- Quaternary International, 332, 61-72. DOI: https://doi.org/10.1016/j. quaint.2014.02.002

Mastronuzzi, G., Valletta, S., Damiani, A., Fiore, A., Francescangeli, R., Giandonato P. B., Iurilli, V. \& L. Sabato (eds.), 2015: Geositi della Puglia. Regione Puglia.

Mazzei, R., Margiotta, S., Foresi, L.M., Riforgiato, F. \& G. Salvatorini, 2009: Biostratigraphy and chronostratigraphy of the Miocene Pietra Leccese in the type area of Lecce (Apulia, southern Italy).- Boll. Soc. Paleont. It., 48, 2, 129-145.

Mongelli, G., Buccione, R. \& R. Sinisi, 2015: Genesis of autochtonous and allochtonous Apulian karst bauxites (Southern Italy): Climate constraints.- Sedimentary Geology, 325, 168-176.

Pandolfi, L., Mannino, M.A., Talamo, S., Salari, L., Sansò, P., Sublimi Saponetti, S., Vacca E., Vicari, D., Richards, M.P. \& C. Petronio, in press: A reassessment of the infills and faunal assemblage of karst cavities known as ventarole in Salento (Apulia, southern Italy): a multidisciplinary investigation on Cava Donno (Corigliano d'Otranto, Lecce).- Alpine and Mediterranean Quaternary, 30 (1), 25 - 40.

Parente, M., 1994: A revised stratigraphy of the Upper Cretaceous to Oligocene units from southeastern Salento (Apulia, southern Italy).- Boll. Soc. Paleont. It., 33, 2, 155-170.
Pepe, M. \& M. Parise, 2014: Structural control on development of karst landscape in the Salento Peninsula (Apulia, SE Italy).- Acta Carsologica, 43, 1, 101114.

Selleri, G., Sansò, P. \& N. Walsh, 2003: The karst of Salento region (Apulia, Southern Italy): constraints for management.- Acta Carsologica, 32, 19-28.

Slabe, T. \& H. Liu, 2009: Significant subsoil rockforms.In: Ginés, A. et al. et al. (eds.) - Karst rock Features. Karren sculpturing. Carsologica, 9, ZRC Publishing, pp. 123-137, Ljubljana.

Slabe, T., 1999: Subcutaneous rock forms.- Acta Carsologica, 28, 2, 255-271.

Tropeano, M., Spalluto, L., Moretti, M., Piero, P. \& L. Sabato, 2004: Depositi carbonatici infrapleistocenici di tipo foramol in sistemi di scarpata (Salento, Italia meridionale).- Il Quaternario, 17, 2, 537-546.

Williams, P.W., 1983: The role of the subcutaneous zone in karst hydrology.- J. Hydrol., 61, 45-67.

Williams, P.W., 2008: The role of the epikarst in karst and cave hydrogeology: a review.- Int. J. Speleol., 37, $1-10$.

Zseni, A., 2009: Subsoil shaping.- In: Ginés, A. et al. (eds.) - Karst rock Features. Karren sculpturing. Carsologica, 9, ZRC Publishing, pp. 103-121, Ljubljana. 